\title{
VEGETATION OF CHENCHA HIGHLANDS IN SOUTHERN ETHIOPIA
}

\author{
Desalegn Wana ${ }^{1}$ and Zerihun Woldu ${ }^{2}$ \\ 1 Department of Geography, Addis Ababa University, PO Box 150178, Addis Ababa, Ethiopia \\ E-mail: deswana@geog.aau.edu.et \\ 2 The National Herbarium, Addis Ababa University, PO Box 3434, Addis Ababa, Ethiopia
}

\begin{abstract}
The relationship between environmental factors and plant communities identified using multivariate numerical analyses were investigated in the highlands of southern Ethiopia. Vegetation data were obtained from relevés placed in belt transects along altitudinal gradients on the mountain slopes following the Arbaminch-Chancha road. The relevés were placed in the two transects which ran for about $30 \mathrm{~km}$ from $1180 \mathrm{~m}$ to $2250 \mathrm{~m}$ along the slope representing a $25 \mathrm{~m}$ vertical distance between each relevés. The relationship among plant communities and environmental factors were established using one way Analysis of Variance (ANOVA). Community transition and species diversity are affected, inter alia, by environmental factors including soil properties, slope and aspect which varied significantly $(\mathrm{P}<0.05)$. The Communities changed along altitudinal gradients as indicated by the high community coefficients of $0.52,0.53$ and 0.16 in between adjacent communities. Species diversity and richness were high in communities between $1250-1800 \mathrm{~m}$. The high species diversity and richness is explained partly by the variations in the environmental factors, which are associated with the effect of altitude.
\end{abstract}

\section{Key words/phrases: Community transitions, environmental factors, species diversity/richness}

Nomenclature follows: Hedberg and Edwards (1989; 1995), Edwards et al. (1995; 1997).

\section{INTRODUCTION}

The distribution, abundance and diversity patterns of species can result from the interaction between the abiotic and biotic factors at different spatial and temporal scales (Brown, 2001). Mountains exhibit great complexity in environmental conditions primarily due to changes in temperature, precipitation and air pressure associated with altitude (Palmer and van Staden, 1992). In the tropics temperature is negatively correlated with altitude while precipitation maintains a nonlinearrelationship with increasing altitude below the cloud level (Walter, 1985). The abundance and diversity of plant species is influenced by the interaction of these two complex gradients and a mid-altitudinal pattern of species diversity can be manifested (Brown and Lomolino, 1998; O'Brien, 1998).

Natural vegetation may respond to gradients in many different ways (Curtis, 1959; Whittaker, 1967). Temperature and moisture gradients along altitude, the nature of substrates, and topographic features such as aspect and their configuration can result in distinct or fuzzy units (Zerihun Woldu et al., 1989; Parker and Bendix, 1996). Huston (1994) has shown that the nature of substrate (e.g., texture) and availability of nutrients, which are mainly the result of geologic processes, influence the pattern of plant communities and diversity. Parker and Bendix (1996) have also pointed out that these features can influence the distribution pattern of individual plants or communities indirectly by regulating microclimatic and hydrological processes in the site. Distinct patches in natural vegetation may be produced through a variety of mechanisms such as anthropogenic influences including the effect of grazing, selective felling, and clearing of the vegetation for cultivation (Forman and Gordon, 1986). Patches may simply interlace and may not show distinct boundaries in areas where there are gradual environmental changes.

Zonal patterns of plant communities are common occurrences in Ethiopia and elsewhere in East African Mountains (Beals, 1969; Zerihun Woldu et al., 1989; Friis, 1992; Tamrat Bekele, 1994; Kebrom Tekle et al., 1997; Weshe, 1999). There is little published work on the south and southwestern part of Ethiopia which could provide 
information for comparative analyses. The purpose of this study is to investigate the transition of plant communities along altitudinal gradient and the relationships between vegetation and environmental factors on the western escarpment of the Rift Valley in the southern part of Ethiopia and make comparisons of the results with those observed in other parts of the country.

\section{MATERIALS AND METHODS}

\section{The study area}

This study was conducted on the western escarpment of the southern part of the Rift Valley in Ethiopia, between $6^{\circ} 05^{\prime} \mathrm{N}$ to $6^{\circ} 12^{\prime} \mathrm{N}$ and $37^{\circ} 33^{\prime} \mathrm{E}$ to $37^{\circ} 45^{\prime} \mathrm{E}$ (Fig. 1). Altitude ranges from $1180 \mathrm{~m}$ to $2250 \mathrm{~m}$. The topography is rugged and ranges from steep slopes on the escarpment of the Rift Valley to nearly flat surface around the shores of L. Abaya. The geology of the lower part of the study area is of recent quaternary volcanic rocks (Mohr, 1971). Volcanic tuffs and effusive basic rocks on the surface are common in the lower course of Hare River (Vukasinovic, 1969). Basalts form the greater part of the trap series and more silicic lavas occur lying above the basalt on the highlands of Chencha (Mohr, 1971). The soils are derived from alluvial and lacustrine deposits of different origins (Vukasinovic, 1969; Mohr, 1971; FAO, 1984) along the Rift Valley and Lake Abaya. Vitric and Mollic Andosols are dominant around Lake Abaya while groups of Nitosols, Cambisols and Vertisols are found along the escarpment and highlands of Chencha (FAO, 1984).

The study area receives bimodal rainfall (Anon, 1988). The two wet seasons are interrupted by two dry seasons in the area. The total annual rainfall recorded around Arbaminch is $800 \mathrm{~mm}$ at $1200 \mathrm{~m}$. and the mean annual temperature is above $26^{\circ} \mathrm{C}$. The mean annual rainfall and temperature of Chencha at the top end of the gradient (2700 m.a.s.l) are $1520 \mathrm{~mm}$ and $15.7^{\circ} \mathrm{C}$, respectively. The vegetation of the area lies within the SomaliaMasai regional centre of endemism as described by White (1983).

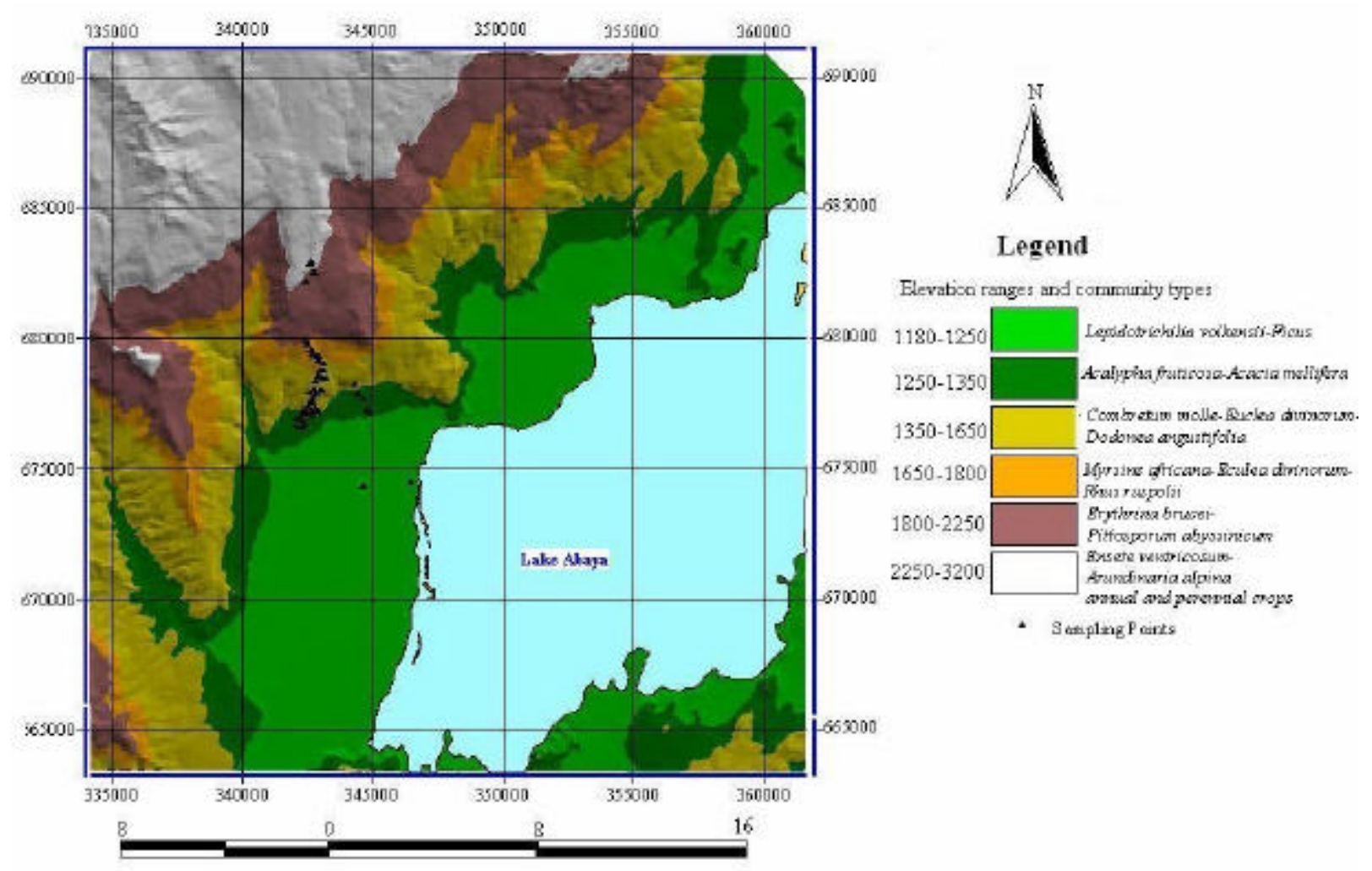

Fig. 1. Map of the study area. 


\section{Vegetation sampling}

Vegetation data were collected in relevés placed in belt transects on the mountain slopes following the altitudinal gradient. A total of 50 relevés were sampled. Relevés were placed in the two transects which ran for about $30 \mathrm{~km}$ from $1180 \mathrm{~m}$ to $2250 \mathrm{~m}$ representing a $25 \mathrm{~m}$ vertical distance (ascent) between each relevés. Forty eight relevés of $20 \mathrm{~m} \mathrm{x}$ $20 \mathrm{~m}$ were laid on the slopes and while 2 relevés of $40 \mathrm{~m} \times 40 \mathrm{~m}$ were placed in the forest at the lakeshore. The percent cover values were visually estimated in the field and later converted into 1-9 modified Braun Blanquet scale (van der Maarel, 1979). Plant specimens encountered in the relevés were collected and brought to the National Herbarium of Addis Ababa University for verification and identification. Data collection was conducted between Nov. and Dec. 2001, which was the period marking the end of the big rainy season in the area (Daniel Gamachu, 1977).

\section{Environmental data}

Slope of each relevé was measured using a Clinometer. Aspect was codified following Zerihun Woldu et al. (1989). Soil samples were collected from each corner and centre of the relevés at $0-30 \mathrm{~cm}$ depth. These were mixed to make a composite sample for each relevé. The soil samples were analyzed for texture, $\mathrm{pH}, \mathrm{CEC}$, Total $\mathrm{N}$, Available P, Percent Organic Matter, in the
Ethiopian Agricultural Research Organization (EARO) soil laboratory at Debre Zeit following standard methods (Jou, 1978).

\section{Vegetation classification and definition of communities}

The Program Package SYNTAX 2000 for windows (Podani, 2000) was used to obtain hierarchical clustering of the data matrix using group average linkage with similarity ratio and correlation coefficient as resemblance indices for the relevés and for the species, respectively. Communities were recognized based on groups of relevés and the associated groups of species. Relevés with similarity level of 0.75 were grouped into the same community (Fig. 2). Principal Component Analysis (PCA) was then used to depict the relationship among communities along the altitudinal gradients (Fig. 3).

\section{Statistical analysis}

The environmental variables of the communities were tested for variation between the means using one-way analysis of variance (ANOVA). Species richness and diversity were measured using Shannon and Wiener (1949) diversity index. Jacquard's coefficient of similarity was used to test for turn over of species composition among successive communities.

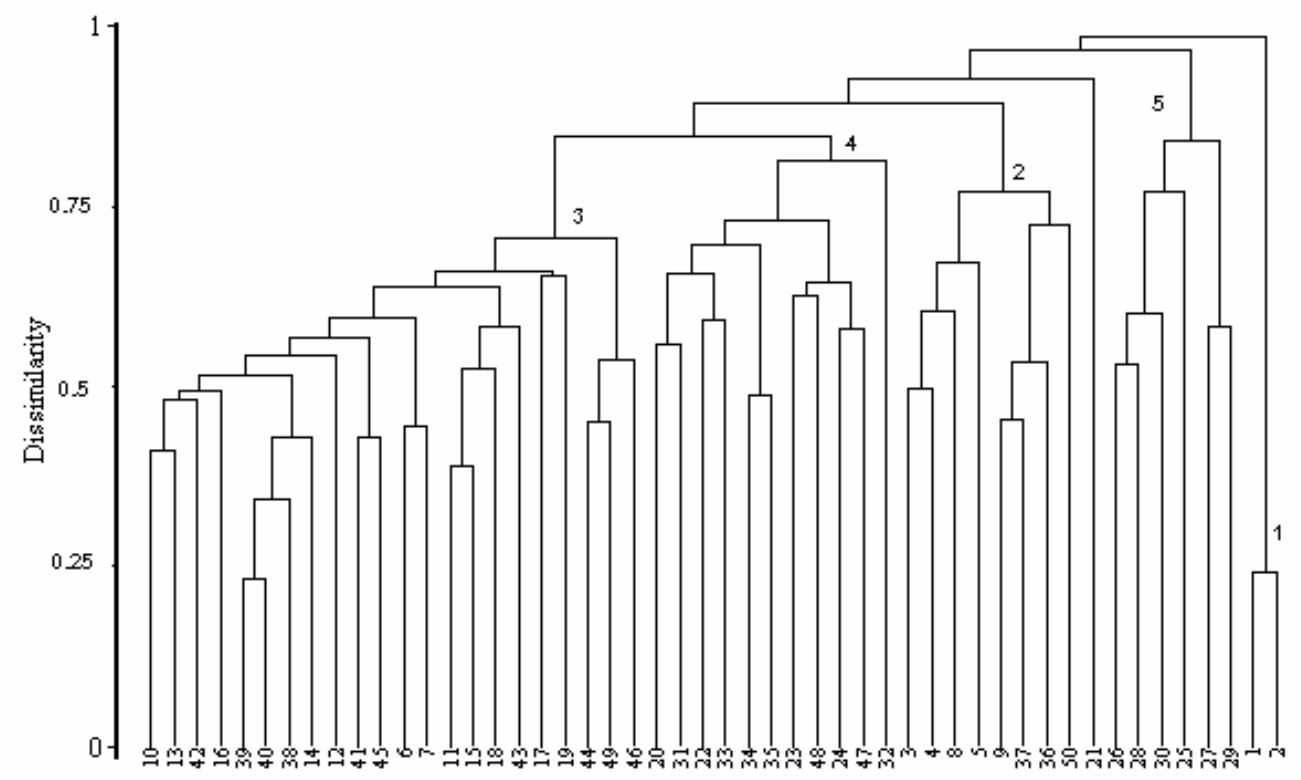

Fig. 2. Dendrogram obtained by the application of agglomerative classification technique at $75 \%$ dissimilarity level. 


\section{RESULTS AND DISCUSSION}

One hundred and seventy four species representing 56 families were encountered in the 50 relevés sampled: 105 tree/shrub, 47 herb, 14 grass, 7 climber and 1 fern species. Eight major families Fabaceae, Poacae, Asteraceae, Acanthaceae, Euphorbiaceae, Lamaceae, Rubiaceae and Combretaceae accounted for $49.9 \%$ of the total number of species. The five communities identified are described below.

\section{Vegetation communities}

1. Lepidotrichilia volkensii-Isoglossa somalensisAchyranthus aspera-Ficus sur - Commicarpus plumbiagineus community: This community is located at lower altitudes in between $1180 \mathrm{~m}$ and 1250 m.a.s.l. Lepidotrichilia volkensii and Ficus sur, attaining a height range of $30 \mathrm{~m}$ to 40 $\mathrm{m}$, dominate the tree layer while the herb layer is dominated by Isoglossa somalensis and Achyranthus aspera with relatively lower cover of Ruellia patula and Hoslundia opposita. The climber Commicarpus plumbiagineus is common species with fairly high cover value in this community. There were as many as 58 seedlings of Prunus africana species in a relevé while there were only few mature trees.

2. Acalypha fruticosa-Acacia mellifera community: This community was found between $1250 \mathrm{~m}$ and 1350 m.a.s.l. Acacia mellifera, Acacia tortilis, Rhus natalensis, Balanites aegyptiaca and Acalypha fruticosa were dominant in the treeshrub layer while Barleria eranthemoides, Melhania ovata, plectheranthus barbatus, Sansieviera sp. and Asparagus flagellaris were dominant in the herb layer. A succulent climber Cissus quadrangularis occurred abundantly in this community. The grass species in this community included Sporobolus pyramidalis, Panicum atrosanguineum and Heteropogon contortus.

3. Combretum molle-Euclea devinorum-Dodonea angustifolia community. This community was found between $1300 \mathrm{~m}$ and 1650 m.a.s.l. Combretum molle, Euclea devinorum, Dodonea angustifolia and Terminalia brownii were dominant species in the tree-shrub layer, while Satureja abyssinica, Justicia calyculata and Barleria eranthemoides were the dominant species in the herb layer. The grass species in this community included Hetropogon contortus, Enteropogon macrostachyus and hyparrhenia hirta in respective order of abundance. Zerihun
Woldu et al. (1989) have indicated that Combretum molle dominantly occurred between $1470-1510 \mathrm{~m}$ in the Bale highlands in the treeshrub layers.

4. Myrsine africana-Euclea devinorum-Rhus ruspolii community. This community was found between $1600 \mathrm{~m}$ and 1800 m.a.s.l. The dominant species in the tree-shrub layer were Myrsine africana, Euclea devinorum, Rhus ruspolii, Combretum collinum and Terminalia brownii while the dominant grass species in this community were Hyparrhenia diplandra, Sporobolus pyramidalis and Hyparrhenia filipendula. Justicia calyculata and Ocimum canum were the dominant species in the herb layer. Climbers including Jasminum grandiflorum, Hippocratea africana and Vigna membranacea were abundant. Jasminum grandiflorum occurred between 1470 and 1820 m.a.s.l in the herb layer in Bale highlands (Zerihun Woldu et al., 1989).

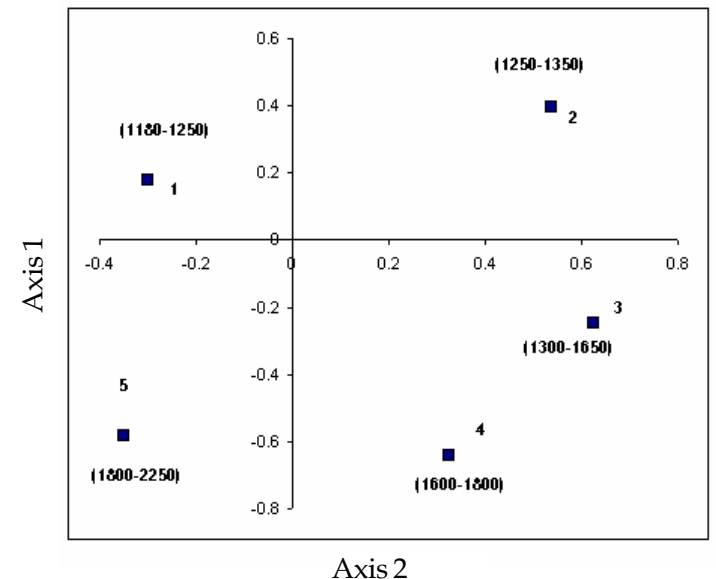

Fig. 3. A PCA scatterplot of the $1^{\text {st }}$ and $2^{\text {nd }}$ axes of the five communities and the Corresponding Altitudinal Ranges.

5. Erythrina brucii-Pittosporum abyssinicum community: This community was found between $1800 \mathrm{~m}$ and $2250 \mathrm{~m}$. The dominant species in the tree-shrub layer were Erythrina brucii, Pittosporum abyssinicum, Bersama abyssinica and Maesa lanceolata. However, species such as Galineria saxifraga, Hagenia abyssinica and Hypericum quartinianum were also abundant in the tree-shrub layer. Rubus stuedneri, a woody scrambler occupied the area between the tree-shrub species. The dominant species in the herb layer were Acanthus eminens and Acanthus pubescens. Moist sites were occupied by Arundinaria alpina. Grass species were not common in this community. Hagenia abyssinica and Arundinaria alpina make part of 
the tree-shrub layer in the Bale highlands at the height of 2350-2800 $\mathrm{m}$ while Acanthus eminens occurred in between 1900 and $2200 \mathrm{~m}$ in the herb layer (Zerihun Woldu et al., 1989).
A synoptic description of the five community types with families, growth forms, life forms and mean species percent cover is given in Table 1 .

Table 1. A Synoptic description of the five vegetation types of patches obtained by cluster analysis. Average species percentage cover in each community, families and growth form and life form of each species are indicated as follows:-Growth forms:-AC $=$ annual climbers, $\mathrm{AG}=$ annual grasses, $\mathrm{AH}=$ annual herb $\mathrm{C}$ $=$ climbers, $\mathrm{HS}=$ high shrubs, $\mathrm{LS}=$ low shrubs, $\mathrm{PC}=$ perennial climbers, $\mathrm{PG}=$ perennial grasses, $\mathbf{P H}=$ perennial herbs, $T$ = Trees. Life forms:-Phanerophytes (Meso: 8-30 m, Micro: 2-8 m, Nano: 0.25-2 $\mathrm{m}$ ) are referred to as MEP, MIP, NAP, respectively. CHP $=$ Chamaephytes $(0-0.25 \mathrm{~m}), \mathrm{HEC}=$ Hemicryptophytes (perennating parts at the soil surface), SUC $=$ Succulent and L: Lianas. Cryptophytes have not been encountered. Life forms were characterized following Raunkaier (1934).

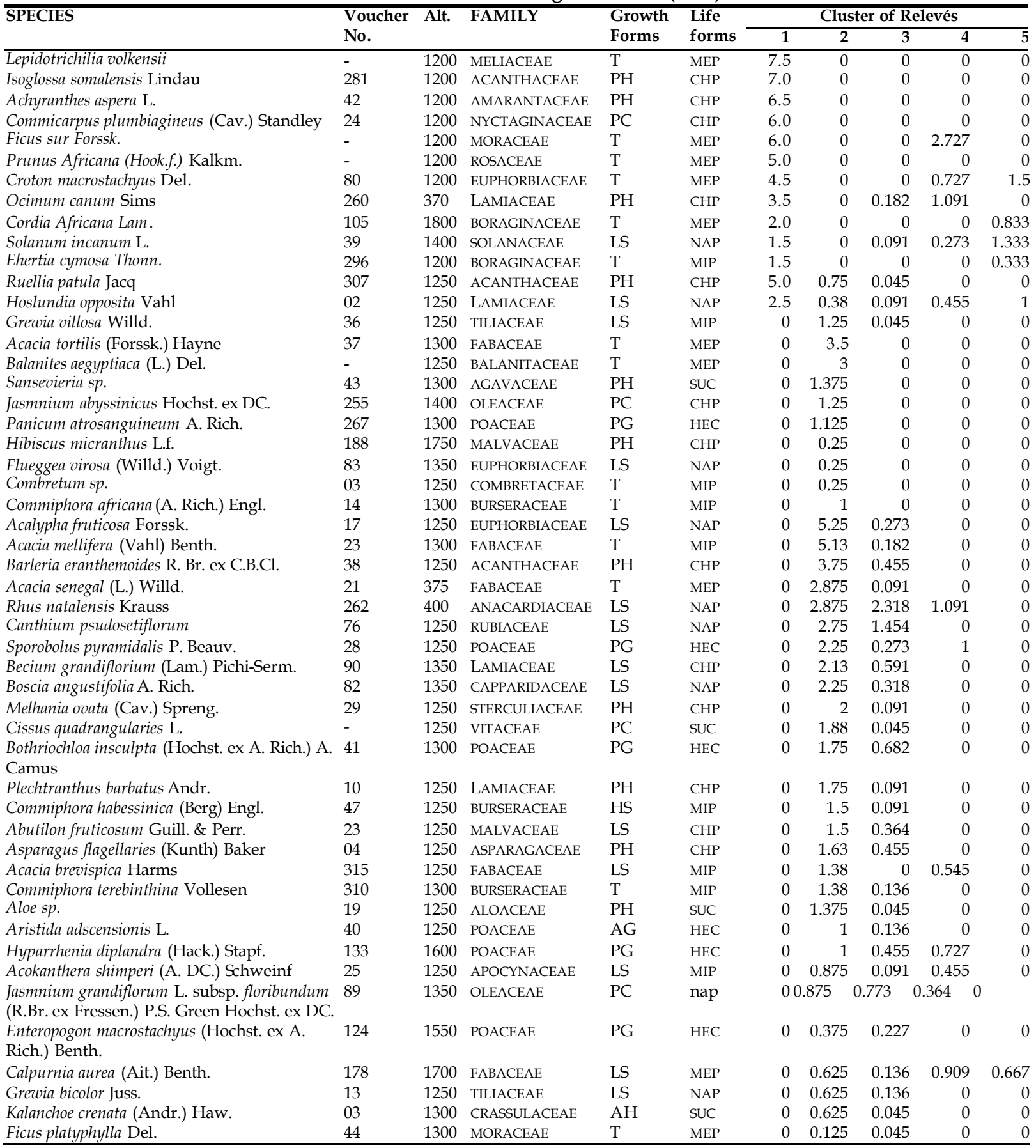


Table 1. (Contd).

\begin{tabular}{|c|c|c|c|c|c|c|c|c|c|c|}
\hline \multirow[t]{2}{*}{ SPECIES } & \multirow{2}{*}{$\begin{array}{l}\text { Voucher } \\
\text { No. }\end{array}$} & \multirow[t]{2}{*}{ Alt. } & \multirow[t]{2}{*}{ FAMILY } & \multirow{2}{*}{$\begin{array}{l}\text { Growth } \\
\text { Forms }\end{array}$} & \multirow{2}{*}{$\begin{array}{l}\text { Life } \\
\text { forms }\end{array}$} & \multicolumn{5}{|c|}{ Cluster of Relevés } \\
\hline & & & & & & 1 & 2 & 3 & 4 & 5 \\
\hline Acacia nilotica (L.) Willd. ex Del. & 31 & 1300 & FABACEAE & $\mathrm{T}$ & MEP & 0 & 375 & 0.136 & 0.273 & $\overline{0}$ \\
\hline Acacia hockii De Wild. & 11 & 1350 & FABACEAE & $\mathrm{T}$ & MIP & 0 & 0.375 & 0.136 & 0 & 0 \\
\hline Cadaba farinosa Forssk. & 30 & 1550 & CAPPARIDACEAE & LS & NAP & 0 & 0.25 & 0.091 & 0 & 0 \\
\hline Dodonea angustifolia L.f. & 53 & 1300 & SAPINDACEAE & LS & MIP & 0 & 0.875 & 5.5 & 1 & 0 \\
\hline Setaria sphacelata (Schumach.) Moss & 315 & 1450 & POACEAE & PG & HEC & 0 & 2.875 & 5.227 & 4.545 & 0.5 \\
\hline $\begin{array}{l}\text { Olea europea L.ssp. Cuspidate (Wall. Ex G. } \\
\text { Don) Cif. }\end{array}$ & 52 & 1400 & OLEACEAE & $\mathrm{T}$ & MEP & 0 & 0 & 4.273 & 0.182 & 0 \\
\hline Harrisonia abyssinica Oliv. & 60 & 1300 & SIMAROUBACEAE & HS & NAP & 0 & 3.25 & 3.273 & 1.636 & 0 \\
\hline Combretum aculeatum Vent. & 35 & 1300 & COMBRETACEAE & $\mathrm{T}$ & MIP & 0 & 2.5 & 3.773 & 2.454 & 0.833 \\
\hline Combretum molle R. Br. Ex G. Don & 54 & 1450 & COMBRETACEAE & $\mathrm{T}$ & MIP & 0 & 2 & 3.546 & 0 & 0 \\
\hline Carisa spinarum $\mathrm{L}$. & 22 & 1300 & APOCYNACEAE & LS & MIP & 0 & 0 & 3.046 & 1 & 0.5 \\
\hline Hyparrhenia hirta (L.) Stapf. & 46 & 1300 & POACEAE & PG & HEC & 0 & 1.5 & 2.454 & 0.455 & 0 \\
\hline Heteropogon contortus (L.) Roem. \& Schult & 72 & 1350 & POACEAE & PG & HEC & 0 & 0.875 & 2.318 & 0.545 & 0 \\
\hline Euclea divinorum Hiern & 01 & 1250 & EBENACEAE & LS & MIP & 0 & 1.25 & 2.318 & 0.273 & 0 \\
\hline Papea capensis Eckl. \& Zeyh. & 96 & 1450 & SAPINDACEAE & $\mathrm{T}$ & MIP & 0 & 0.75 & 2.364 & 0 & 0 \\
\hline Terminalia brownii Fresen. & 74 & 1350 & COMBRETACEAE & $\mathrm{T}$ & MEP & 0 & 0.125 & 2.273 & 0.818 & 0 \\
\hline Dichrostachys cinerea (L.) Wight \& Arn. & 118 & 1550 & FABACEAE & HS & MIP & 0 & 0.75 & 2.091 & 0 & 0 \\
\hline Ozoroa insignis Del. & 71 & 1350 & ANACARDIACEAE & $\mathrm{T}$ & MIP & 0 & 0 & 1.454 & 0.545 & 0 \\
\hline Leucas stachydiformis (Benth.) Briq. & 121 & 1550 & LAMIACEAE & LS & NAP & 0 & 0.125 & 1.364 & 0.636 & 0.5 \\
\hline Myrica salicifolia A. Rich. & 106 & 1450 & MYRICACEAE & $\mathrm{T}$ & MIP & 0 & 0.375 & 1.227 & 1.182 & 0 \\
\hline Crotalaria laburnifolia $\mathrm{L}$. & 86 & 1350 & FABACEAE & LS & NAP & 0 & 1.25 & 1.273 & 0 & 0 \\
\hline Maytenus senegalensis (Lam.) Exell & 69 & 1350 & CELASTERACEAE & $\mathrm{T}$ & MIP & 0 & 0 & 0.909 & 0.545 & 0.833 \\
\hline Ximenia americana $\mathrm{L}$. & 80 & 1300 & OLACACEAE & HS & MIP & 0 & 0 & 0.5 & 0.091 & 0 \\
\hline Lantana camara $\mathrm{L}$. & 187 & 1750 & VERBENACEAE & LS & NAP & 0 & 0 & 0.591 & 0 & 0 \\
\hline Tephrosia emeroides A. Rich. & 79 & 1350 & FABACEAE & LS & NAP & 0 & 0 & 0.545 & 0.091 & 0 \\
\hline Gomphocarpus fruticosus (L.) Ait.f. & 86 & 1350 & ASCLEPIADACEAE & $\mathrm{PH}$ & $\mathrm{CHP}$ & 0 & 0 & 0.727 & 0.455 & 0 \\
\hline Manilkara butugi Chiov. & 88 & 1350 & SAPOTACEAE & $\mathrm{T}$ & MRP & 0 & 0 & 0.318 & 0 & 0 \\
\hline Gardenia ternifolia Schumach. \& Thonn & 105 & 550 & RUBIACEAE & HS & MIP & 0 & 0 & 0.955 & 0.364 & 0 \\
\hline Osyris quadripartita Decn. & 77 & 1650 & SANTALACEAE & LS & NAP & 0 & 0 & 0.318 & 0.273 & 0 \\
\hline Bridelia micrantha (Hochst.) Baill. & 108 & 1575 & EUPHORBIACEAE & $\mathrm{T}$ & MIP & 0 & 0 & 0.318 & 0.273 & 0 \\
\hline Ziziphus mucronata Willd. & 303 & 1350 & RHAMNACEAE & HS & MEP & 0 & 0 & 0.091 & 0 & 0 \\
\hline Pavetta sp. & 317 & 1575 & RUBIACEAE & LS & MIP & 0 & 0.125 & 0.136 & 0.091 & 0 \\
\hline Justicia calyc & 16 & 1250 & ACANTHACEAE & $\mathrm{PH}$ & CHP & 0 & 0 & 0.045 & 0.091 & 0 \\
\hline Desmodium velutinum (Willd.) DC. & 117 & 1550 & FABACEAE & LS & $\mathrm{CHP}$ & 0 & 0 & 0.545 & 0.545 & 0 \\
\hline Maytenus arbutifolia (A. Rich.) Wilczek & 129 & 1600 & CELASTERACEAE & $\mathrm{T}$ & MIP & 0 & 1 & 0.773 & 5.091 & 1 \\
\hline Indigofera atriceps Hook.f. & 115 & 1650 & FABACEAE & LS & NAP & 0 & 0 & 0.318 & 3.546 & 0 \\
\hline Helichrysum odoratissium & 185 & 1750 & ASTERACEAE & $\mathrm{PH}$ & $\mathrm{CHP}$ & 0 & 0 & 0.045 & 2.546 & 0 \\
\hline Rhus ruspolii Engl. & 103 & 1550 & ANACARDIACEAE & HS & MIP & 0 & 0 & 0.864 & 2.727 & 0.667 \\
\hline Myrsine africana $\mathrm{L}$. & 131 & 1600 & MYRSINACEAE & LS & NAP & 0 & 0 & 1.182 & 4.273 & 0.833 \\
\hline Clutia abyssinica Jaub. \& Spach. & 119 & 1550 & EUPHORBIACEAE & LS & NAP & 0 & 0 & 0.136 & 2.091 & 0 \\
\hline Combretum collinum Fresen. & 111 & 1550 & COMBRETACEAE & $\mathrm{T}$ & MIP & 0 & 0 & 0.273 & 1.091 & 0.333 \\
\hline Allophyllus rubifolis (A. Rich) Engl. & 100 & 1500 & SAPINDACEAE & LS & NAP & 0 & 0 & 0 & 1.909 & 0.333 \\
\hline Hippocratea Africana (Willd.) Loes. & 110 & 1575 & CELASTERACEAE & PC & $\mathrm{L}$ & 0 & 0 & 0.409 & 2.091 & 1.5 \\
\hline Pluchea disioscoridis (L.) DC. & 125 & 1600 & ASTERACEAE & $\mathrm{PH}$ & $\mathrm{CHP}$ & 0 & 0 & 0.091 & 1.091 & 0 \\
\hline Hyparrhenia filipendula (Hochst.) Stapf & 65 & 1300 & POACEAE & PG & HEC & 0 & 0.5 & 1.227 & 1.273 & 0 \\
\hline Flacourtia indica (Burm.f.) Merr. & 107 & 1500 & FLACOURTIACEAE & HS & MIP & 0 & 0 & 0.591 & 0.818 & 0 \\
\hline Albizia gummifera (J.F.Gmel.) C.A.Sm. & 299 & 1750 & FABACEAE & $\mathrm{T}$ & MEP & 0 & 0 & 0 & 0.818 & 0.5 \\
\hline Hyparrhenia collina (Pilg) Stapf. & 45 & 1300 & POACEAE & PG & HEC & 0 & 0 & 0 & 0.455 & 0.167 \\
\hline Acanthus eminens C.B.Clarke & 252 & 2250 & ACANTHACEAE & LS & NAP & 0 & 0 & 0 & 0.455 & 0 \\
\hline Clausena anisata (Willd.) Benth. & 288 & 1750 & RUTACEAE & LS & MIP & 0 & 0 & 0.136 & 0.636 & 0.5 \\
\hline Rhamnus staddo A. Rich. & 183 & 1750 & RHAMNACEAE & $\mathrm{T}$ & MIP & 0 & 0 & 0 & 0.364 & 0 \\
\hline Vigna membranacea A. Rich. & 184 & 1750 & FABACEAE & PC & $\mathrm{L}$ & 0 & 0 & 0.045 & 0.455 & 0 \\
\hline Terminalia laxiflora Engl. \& Diels & 144 & 1350 & COMBRETACEAE & $\mathrm{T}$ & MEP & 0 & 0 & 0 & 0.818 & 0.333 \\
\hline Eucalyptus globulus Labill. & 207 & 1900 & MYRTHACEAE & $\mathrm{T}$ & MEP & 0 & 0 & 0 & 0.545 & 0 \\
\hline Crotalaria incana $\mathrm{L}$. & 190 & 750 & FABACEAE & LS & NAP & 0 & 0 & 0 & 0.636 & 0 \\
\hline Dissotis senegambiensis (Guill. \& Perr.) Triana & 287 & 1750 & MELASTOMATACEA & IPH & $\mathrm{CHP}$ & 0 & 0 & 0.318 & 0.364 & 0 \\
\hline Acacia etbiaca Schweinf. & 64 & 1300 & FABACEAE & $\mathrm{T}$ & MEP & 0 & 0 & 0.136 & 0.364 & 0 \\
\hline Setureja abyssinica (Benth.) Briq. & 112 & 1550 & LAMIACEAE & $\mathrm{H}$ & $\mathrm{CHP}$ & 0 & 0 & 0.364 & 0.545 & 0 \\
\hline Cussonia holstii Harms ex Engl. & 319 & 1250 & ARALIACEAE & $\mathrm{T}$ & MIP & 0 & 0 & 0.091 & 0.364 & 0 \\
\hline Aeschynomene abyssinica (A. Rich.) Vatke & 95 & 1550 & FABACEAE & LS & MIP & 0 & 0.25 & 0.091 & 0.455 & 0 \\
\hline Syzygium guineense (Willd.) DC. & 138 & 1650 & MYRTACEAE & $\mathrm{T}$ & MEP & 0 & 0 & 0.455 & 0.364 & 5 \\
\hline Allophyllus abyssinicus (Hochst.) Radlkofer & 45 & 1750 & SAPINDACEAE & $\mathrm{T}$ & MEP & 0 & 0 & 0.136 & 0.364 & 4.333 \\
\hline Conyza schimperi Sch. Bip. ex A. Rich. & 209 & 1950 & ASTERACEAE & LS & CHP & 0 & 0 & 0 & 0.545 & 3.5 \\
\hline Maesa lanceolata Forssk. & 192 & 1800 & MYRSINACEAE & $\mathrm{T}$ & MEP & 0 & 0 & 0 & 1 & 3.5 \\
\hline Bersama abyssinica Fresen. & 176 & 1700 & MELIANTHACEAE & $\mathrm{T}$ & MEP & 0 & 0 & 0 & 0 & 3.167 \\
\hline Pittosporum abyssinicum Del & 221 & 2250 & PITTOSPORACEAE & LS & MIP & 0 & 0 & 0 & 0 & 2.833 \\
\hline Galiniera saxifraga (Hochst.) Bridson. & 222 & 2150 & RUBEACEA & $\mathrm{T}$ & MEP & 0 & 0 & 0 & 0 & 2.333 \\
\hline Albizia schimperiana Oliv. & 132 & 1600 & FABACEAE & $\mathrm{T}$ & MEP & 0 & 0 & 0 & 0 & 2.667 \\
\hline
\end{tabular}


Table 1. (Contd).

\begin{tabular}{|c|c|c|c|c|c|c|c|c|c|c|}
\hline \multirow[t]{2}{*}{ SPECIES } & \multirow{2}{*}{$\begin{array}{l}\text { Voucher } \\
\text { No. }\end{array}$} & \multirow[t]{2}{*}{ Alt. } & \multirow[t]{2}{*}{ FAMILY } & \multirow{2}{*}{$\begin{array}{l}\text { Growth } \\
\text { Forms }\end{array}$} & \multirow{2}{*}{$\begin{array}{l}\text { Life } \\
\text { forms }\end{array}$} & \multicolumn{5}{|c|}{ Cluster of Relevés } \\
\hline & & & & & & 1 & 2 & 3 & 4 & 5 \\
\hline Aspilia mossambicensis (Oliv.) Wild. & 8 & 1250 & ASTERACEAE & $\mathrm{PH}$ & $\mathrm{CHP}$ & 0 & 0 & 0 & 0.818 & 2.5 \\
\hline Asplenium bugoiense Hieron & 230 & 2150 & ASPLENIACEAE & $\mathrm{AH}$ & $\mathrm{CHP}$ & 0 & 0 & 0.091 & 0.182 & 1.5 \\
\hline Arundinaria alpina K. Schum. & 240 & 2200 & POACEAE & PG & HEC & 0 & 0 & 0 & 0.636 & 1.833 \\
\hline Erythrina brucei Schweinf. & 102 & 1500 & FABACEAE & $\mathrm{T}$ & MEP & 0 & 0 & 0 & 0 & 1.833 \\
\hline Euphorbia ampliphylla Pax & 251 & 2200 & EUPHORBIACEAE & $\mathrm{T}$ & MIP & 0 & 0 & 0 & 0 & 1.667 \\
\hline Hagenia abyssinica (Bruce) J.F. Gmel. & 280 & 2250 & ROSACEAE & $\mathrm{T}$ & MEP & 0 & 0 & 0 & 0 & 1 \\
\hline Ocimum urticifolium Roth. & 291 & 2200 & LAMIACEAE & LS & $\mathrm{CHP}$ & 0 & 0 & 0 & 0.273 & 1.333 \\
\hline Hallea rubrostipulata (K. Schum.) J.-F. Leroy & 291 & 1600 & RUBIACEAE & $\mathrm{T}$ & MIP & 0 & 0 & 0 & 0 & 1.333 \\
\hline Rubus steudneri Schweinf. & 196 & 1800 & ROSACEAE & PC & $\mathrm{L}$ & 0 & 0 & 0.045 & 0.545 & 1 \\
\hline Acanthus pubescens (Thoms.) Engl. & 175 & 2250 & ACANTHACEAE & LS & NAP & 0 & 0 & 0 & 0.273 & 1 \\
\hline Hibiscus crassinervius Hochst. ex A. Rich. & 177 & 1750 & MALVACEAE & LS & NAP & 0 & 0 & 0 & 0 & 0.833 \\
\hline Ficus glumosa Del. & 173 & 1650 & MORACEAE & $\mathrm{T}$ & MEP & 0 & 0 & 0 & 0.182 & 0.833 \\
\hline Rhamnus prinoides & 198 & 1700 & RHAMNACEAE & LS & NAP & 0 & 0 & 0 & 0 & 0.833 \\
\hline Hypericum quartinianum A. Rich. & 182 & 1750 & HYPRERICACEAE & LS & NAP & 0 & 0 & 0 & 0.091 & 0.5 \\
\hline Pavetta oliveriana Hiern & 317 & 1575 & RUBIACEAE & LS & MIP & 0 & 0.125 & 0 & 0 & 0.5 \\
\hline
\end{tabular}

-Species identified on the spot

\section{Altitudinal gradient of communities and diversity}

The distribution of plant communities on the mountain slope of the study area clearly signifies the influence of altitude and the associated environmental factors. Even though communities were identified on the basis of dominant species, the species composition and diversity changed gradually along the altitude. This is indicated by the high Jaccard's coefficient of similarity among communities, eg. community 3 shared high number of species with communities 2,4 and 5 . On the other hand, communities 3 and 1 shared only a few species. Community 1 had the lowest similarity with all other communities apparently because of its location at the lakeshore (Table 2) where the terrain is flat and the OM composition of the soil is high (Table 5).

Table 2. Jaccard's community coefficient among 5 communities.

\begin{tabular}{clllll}
\hline Communities & 1 & 2 & 3 & 4 & 5 \\
\hline 1 & 1.00 & & & & \\
2 & 0.04 & 1.00 & & & \\
3 & 0.05 & 0.53 & 1.00 & & \\
4 & 0.07 & 0.20 & 0.52 & 1.00 & \\
5 & 0.11 & 0.07 & 0.16 & 0.36 & 1.00 \\
\hline
\end{tabular}

There was abrupt transition between communities 1 and 2 with only $4 \%$ of species occurring between them (Table 3). The transition between community 2 and community 3 was not as abrupt as between communities 1 and 2 with $53 \%$ of species being common to both communities. Communities 3 and 4 also had $52 \%$ of the species in common. The share of species between community 4 and 5 was only $36 \%$.

Table 3. Jaccard's community coefficient among adjacent communities/altitudinal ranges.

\begin{tabular}{lcc}
\hline Altitudinal Ranges & $\begin{array}{l}\text { Similarity } \\
\text { coefficient }\end{array}$ & Communities \\
\hline $1180-1250 / 1250-1350$ & $4 \%$ & 1,2 \\
$1250-1350 / 1300-1650$ & $53 \%$ & 2,3 \\
$1300-1650 / 1600-1800$ & $52 \%$ & 3,4 \\
$1600-1800 / 1800-2250$ & $36 \%$ & 4,5 \\
\hline
\end{tabular}

The pattern observed in this study indicated that community composition turnover was gradual as exhibited by high similarity coefficients among altitudinal ranges (Table 3). Even though continuity of vegetation composition was widely observed in the study area, there was discontinuity of vegetation composition between communities 1 and 2 at an altitude of $1250 \mathrm{~m}$ and between communities 4 and 5 at an altitude of $1800 \mathrm{~m}$. The difference in the nature of the substrate could be important in causing breaks in community transitions at $1250 \mathrm{~m}$. The geology on the highlands of Chencha is mainly composed of tertiary basalt while that of the Rift Valley floor is recent volcanic and tuffs of the quaternary (Vukasinovic, 1969; Mohr, 1971). In this connection, Beals (1969) had observed the effect of substrate discontinuity on the community patterns along the escarpment of the Rift Valley in Bati, Wello. The relative abruptness in the transition of communities at $1800 \mathrm{~m}$ could be attributed to the disturbances accounted by the activities of exotic tree plantations. 
The diversity of species also showed gradual change among communities as altitude increases (Table 4). Community 3 had the highest species richness while community 5 exhibited the least species richness. The species richness showed bellshaped pattern along altitudinal gradients, with the peak at the intermediate elevation and declining pattern at the lower and upper altitudes.

Table 4. Shannon-Wiener Diversity Index (using $\mathrm{H}=$ -sum pi ln pi).

\begin{tabular}{clll}
\hline Communities & Richness & $\begin{array}{l}\text { Diversity } \\
\text { Index }(\mathrm{H})\end{array}$ & $\begin{array}{l}\text { Evenness } \\
\text { (H/HMAX) }\end{array}$ \\
\hline 1 & 45 & 3.527 & 0.927 \\
2 & 63 & 3.826 & 0.923 \\
3 & 89 & 3.75 & 0.835 \\
4 & 76 & 3.891 & 0.898 \\
5 & 16 & 2.478 & 0.894 \\
\hline
\end{tabular}

On the other hand, communities 1 and 2 had more even representation of the species followed by communities 4 and 5 . Community 3 had high richness and lowest evenness. Community 4 and community 2 had the highest species diversity (3.89 and 3.82) followed by community 3 and 1 . Community 5 had the lowest species diversity and richness than others (Table 4).

The relationship between communities and environmental variables

The test for variance of soil physical and chemical properties shown in Table 5 reveals that the differentiation of communities can be partly explained by the variations of soil texture and chemical properties at $5 \%$ probability, except cation exchange capacity, which was not significant (Table 5).
The mean values for soil particle size distribution were highly variable. The proportion of sand can be related to the degree of steepness since it was highest in community 2 and lowest in community 1 (Table 5). The proportion of clay particle size was highest in community 4 while it was lowest in community 2 . The test for significance of variation of soils physical properties exhibited that soil particle size distribution appears to explain some variation among communities. The mean $\mathrm{pH}$ values in the five communities ranged between 5.83 and 7.4. Communities 5, 4 and 3 were found in slightly acidic soils while communities 2 and 1 were found in neutral to slightly basic soils at lower elevations. Similar result was reported by Beals (1969) regarding the increase of soil acidity with altitude.

Organic matter content and total nitrogen also varied among communities with out significant interaction between themselves. The communities could be arranged in decreasing order of: (i) soil organic matter as 1, 5, 3, 4 and 2 (ii) while total nitrogen as 2, 5, 4, 3 and 1 . The communities can be arranged in decreasing order of available phosphorous (Ppm) as 1, 5, 2, 4, and 3 indicating a significant positive correlation with soil organic matter content $(\mathrm{P}=0.037)$. The highest organic matter content $(5.52 \%)$ in community 1 at lower elevation (1180-1250 m) appears to be the effect of poor drainage (Haynes, 1986) along the lakeside.

Community 5 had low diversity and richness apparently due to the higher total nitrogen and available Phosphorous content of the soil apart from the obvious effect of temperature decline with increasing altitude. This agrees with the generally held view that highly nutrient rich soils would tend to support low species diversity (Hall and Swaine, 1976; Huston, 1994).

Table 5. Mean values of Soil Physical/Chemical properties, slope and aspect (ANOVA, F ratio at $\mathrm{P}<0.05 \mathrm{df}=4$ and 44).

\begin{tabular}{|c|c|c|c|c|c|c|}
\hline $\begin{array}{l}\text { Environmental } \\
\text { Variables }\end{array}$ & $\begin{array}{l}\text { Community } 1 \\
1180-1250 \mathrm{~m}\end{array}$ & $\begin{array}{l}\text { Community } 2 \\
1250-1350 \mathrm{~m}\end{array}$ & $\begin{array}{l}\text { Community } 3 \\
1300-1650\end{array}$ & $\begin{array}{l}\text { Community } 4 \\
1600-1800 \mathrm{~m}\end{array}$ & $\begin{array}{l}\text { Community } 5 \\
1800-2250 \mathrm{~m}\end{array}$ & $\begin{array}{l}\text { F ratio } \\
(\mathrm{P}<0.05)\end{array}$ \\
\hline \%Sand & 19.98 & 50.50 & 34.39 & 30.21 & 33.07 & $4.87^{*}$ \\
\hline$\%$ Silt & 40.02 & 32.65 & 25.60 & 24.72 & 31.20 & $2.67^{*}$ \\
\hline$\%$ Clay & 40.06 & 16.84 & 40.62 & 45.05 & 35.72 & $6.62 *$ \\
\hline $\mathrm{pH}$ & 7.40 & 7.23 & 6.63 & 6.33 & 5.83 & $6.41^{*}$ \\
\hline CEC & 35.30 & 46.51 & 44.55 & 39.64 & 40.53 & $1.03^{* *}$ \\
\hline \%Organic Matter & 5.52 & 2.03 & 2.90 & 2.84 & 3.72 & $3.59^{*}$ \\
\hline \%Total Nitrogen & 0.25 & 2.97 & 2.53 & 2.59 & 2.83 & $4.45^{*}$ \\
\hline Pppm & 96.63 & 3.14 & 1.25 & 2.83 & 4.43 & $854.46^{*}$ \\
\hline Slope $\left(^{\circ}\right)$ & 1 & 8.5 & 5.91 & 8.36 & 6.83 & $4.28^{*}$ \\
\hline Aspect & -1 & 2.01 & 1.72 & 2.34 & 2.42 & $4.81^{*}$ \\
\hline
\end{tabular}

*Significant ** not significant 
The overall pattern of the vegetation on the Arbaminch-Chencha mountain slope owes partly to the relatively low disturbance as a result of reduced population of the livestock which is checked by the occurrence of trypanosomiasis. The current effort to eradicate the tsetse flies and hence the disease could in due course affect the composition of the vegetation. It is therefore necessary to consider the possible scenario of tsetse eradication in conserving the environment in the area.

\section{CONCLUSION}

The distribution, abundance and diversity of species along altitudinal gradient on the slopes of Arbaminch-Chencha highlands are influenced by the variation of environmental factors across the landscape. The variability in topographic and edaphic conditions along slopes have resulted in spatial variations in environmental factors and influence the vegetation attributes such as composition, distribution and diversity of species. Aspect and soil physical and chemical properties appear to be the most highly influential factors on the distribution and diversity of species along the altitude. The study showed that the distribution of community types, species composition and diversity are better understood through investigation of environmental factors along altitudinal gradients on mountain slopes.

\section{ACKNOWLEDGEMENTS}

This study was supported by the school of Graduate Studies, Addis Ababa University. The first author would like to thank Woldeamlak Bewket for comments on the first draft of the manuscript. We extend our sincere thanks to the anonymous reviewers of SINET for their critical comments.

\section{REFERENCES}

1. Anon (1988). National Atlas of Ethiopia. Ethiopian Mapping Authority, Addis Ababa.

2. Beals, E.W. (1969). Vegetational change along altitudinal gradients. Science 165:981-985.

3. Brown, J.H. and Lomolino, M.V. (1998). Biogeography, $2^{\text {nd }}$ ed. Sinauer Associates, Inc. Publishers, Sunderlands MA.
4. Brown, J.H. (2001). Mammals on mountainsides: elevational patterns of diversity. Global Ecology and Biogeography 10:101-109.

5. Curtis, J.T. (1959). The Vegetation of Wisconsin: An Ordination of Plant Communities. Univ. Wisconsin Press, Madison, pp. 657.

6. Daniel Gamachu (1977). Aspects of Climate and Water Budget in Ethiopia. Addis Ababa University Press, Addis Ababa.

7. Edwards, S., Mesfin Tadesse and Hedberg, I. (1995). Flora of Ethiopia and Eritrea, Vol. 2, part 2. The National Herbarium, Addis Ababa.

8. Edwards, S., Sebsebe Demissew and Hedberg, I. (1997). Flora of Ethiopia and Eritrea, Vol. 6. The National Herbarium, Addis Ababa.

9. FAO (1984). Assistance to Landuse Planning, Ethiopia: Geomorphology and Soils. FAO, Addis Ababa.

10. Forman, R. and Gordon, M. (1986). Landscape Ecology. John Wiley and Sons, New York.

11. Friis, I. (1992). Forests and Forest Trees of Northeast Tropical Africa: Their Natural Habitats and Distribution Patterns in Ethiopia, Djibouti and Somalia. Kew Bulletin Additional Series XV, HMSO, London.

12. Hall, J.B. and Swaine, M.D. (1976). Classification and ecology of closed-canopy forest in Ghana. J. Ecology 64:913-951.

13. Haynes, R.J. (1986). Mineral Nitrogen in the Plant-Soil System. Academic Press, Or elando, Florida.

14. Hedberg, I. and Edwards, S. (1989). Flora of Ethiopia, Vol. 3. The National Herbarium, Addis Ababa.

15. Hedberg, I. and Edwards, S. (1995). Flora of Ethiopia and Eritrea, Vol. 7. The National Herbarium, Addis Ababa.

16. Huston, M. (1994). Biological Diversity: The Coexistence of Species in Changing Landscapes. Cambridge University Press, Cambridge.

17. Jou, A.S.R. (1978). Selected Methods for Soil and Plant Analysis, International Institute of Tropical Agriculture, Ibadan, Nigeria.

18. Kebrom Tekle, Backeus, I., Skoglund, J. and Zerihun Woldu (1997). Vegetation on hill slopes in southern Wello, Ethiopia: Degradation and Regeneration, Nord. J. Bot. 17:483-493.

19. Mohr, P. (1971). The Geology of Ethiopia, 2nd ed. HSIU press, Addis Ababa.

20. O'Brien, E.M. (1998). Water energy dynamics, climate, and prediction of woody plant species richness. Journal of Biogeography 25:379-398.

21. Palmer, A.R. and van Staden, J. (1992). Predicting the distribution of plant communities using annual rainfall and elevation: An example from Southern Africa. J.Veg.Sc. 3:261-266. 
22. Parker, K.C. and Bendix, J. (1996). Landscape scale geomorphic Influences on vegetation patterns on four environments. Physical Geography 17:113-141.

23. Podani, J. (2000). Syntax 2000. Department of Plant Taxonomy and Ecology, LEÖTVÖS University, Hungary.

24. Raunkaier, C. (1934). The Life Forms of Plants and Statistical Plant Geography. Oxford, Clerandon.

26. Shannon, C.E. and Wiener, W. (1949). The Mathematical Theory of Communication. University of Illinois Press, Urbana III.

27. Tamrat Bekele (1994). Phytosociology and ecology of a humid of Ethiopia Afromontane Forest on the central plateau. J. Veg. Sc. 5:1-12.

28. van der Maarel, E. (1979). Transformation of coverabundance values and its effects on community similarity. Vegetation 39:97-114.

29. Vukasinovic, S. (1969). Report and Interpretation of the Pedological Investigations in the Harre
Region, Near Arbaminch, Gamo Gofa Province, Zurich (Switzerland).

24. Walter, H. (1985). Vegetation of the Earth and Ecological Systems of the Geobiosphere, $3^{\text {rd }}$ ed. SpringerVerlag, Berlin.

25. Weshe, K. (1999). The High-Altitude Environment of Mt. Elgon (Uganda/Kenya)-Climate, Vegetation and impact of Fire. PhD Dissertation, der Pilipps-Universität, Germany.

26. White, F. (1983). The Vegetation of Africa: A descriptive Memoir to Accompany the UNESCO/AETFAT/UNESCO vegetation Map of Africa. Natural Resource Research 20, UNESCO, Paris.

27. Whittaker, R.H. (1967). Gradient Analysis of Vegetation. Biol. Rev. 49:207-264.

28. Zerihun Woldu, Feoli, E. and Lisanework Nigatu (1989). Partitioning an elevational gradient of vegetation from southeastern Ethiopia by probabilistic methods. Vegetation 81:189-198. 